Article

\title{
Trace Mineral Leaching from Equine Compost
}

\author{
Ashley L. Fowler ${ }^{1, * \mathbb{D}}$, Mieke Brummer-Holder ${ }^{1} \mathbb{D}$ and Karl A. Dawson ${ }^{2}$ \\ 1 Department of Animal and Food Sciences, University of Kentucky, Lexington, KY 40546, USA; \\ mieke.holder@uky.edu \\ 2 Center for Animal Nutrigenomics and Applied Animal Nutrition, Alltech Inc., Nicholasville, KY 40356, USA; \\ kadawson@alltech.com \\ * Correspondence: ashleyfowler@uky.edu
}

Received: 11 August 2020; Accepted: 29 August 2020; Published: 2 September 2020

check for updates

\begin{abstract}
Mineral leaching from compost can be environmentally disruptive. Little information is available regarding trace mineral leaching from equine-sourced compost. The objective of this study was to quantify the mineral content and leaching potential of compost produced from feces of horses fed different amounts and forms (organic or inorganic) of trace minerals. Nine horses were fed three treatments in a $3 \times 3$ replicated Latin Square design. The dietary treatments were provided as a daily pellet: CON (pellet without added trace minerals), ING (added inorganic trace minerals), and ORG (added organic trace minerals). The added trace minerals were $\mathrm{Co}, \mathrm{Cu}, \mathrm{Mn}$, and $\mathrm{Zn}$. Feces were collected from each horse after a 16-day feeding period, combined with straw, composted, and then subjected to simulated rainfall to measure mineral mobility. Concentrations of $\mathrm{Co}, \mathrm{Cu}, \mathrm{Mn}$, and $\mathrm{Zn}$ were greater in ING and ORG compared to CON compost $(p<0.05)$; additionally, ING had greater $\mathrm{Zn}$ than ORG compost $(p<0.05)$. More $\mathrm{Cu}$ leached from ING and ORG compared to CON $(p<0.05)$. The most Zn leached from ING, followed by ORG, and the least amount leached from CON compost $(p<0.05)$. Dietary trace mineral intake affected the trace mineral concentration in the compost and amount available to leach during rainfall events.
\end{abstract}

Keywords: compost; copper; horse; organic mineral; zinc

\section{Introduction}

Horses produce a considerable amount of manure. An average-sized 500-kg horse produces approximately $22.7 \mathrm{~kg}$ of manure per day [1]. With the addition of bedding material, the total waste generated from a single horse can accumulate to over $9400 \mathrm{~kg}$ per year [2,3]. Composting is a beneficial management practice that can reduce the volume of manure, reduce pathogen load, improve the stability of the nutrients, and produce a value-added material [4].

In a survey of New Jersey horse farms, $47 \%$ of respondents reported composting their horse manure, although best management practices for composting were not recorded [5]. Without proper management of compost piles, nutrients have the potential to leach from the pile and contribute to environmental issues, such as eutrophication.

Most of the mineral leaching research using equine-sourced compost has mainly focused on N, $\mathrm{P}$, and $\mathrm{K}$. One study reported that during a single rain storm, between 28 and $93 \mathrm{mg} \mathrm{P} / \mathrm{kg}$ ran off from uncovered equine manure compost piles [2]. Over the course of the entire composting process involving multiple rain events, approximately $69 \%$ of initial $\mathrm{P}$ had disappeared from the compost pile [2]. In another experiment using equine straw-based compost, $7 \%$ of the initial $\mathrm{P}$ and $6 \%$ of the initial $\mathrm{N}$ leached during one simulated rainfall event [6].

While N, P, and $\mathrm{K}$ are important to consider in composting systems from an environmental standpoint, trace minerals should also be considered. When applied to the land, compost can provide 
beneficial minerals to support plant growth [7]. However, if manure or compost is applied in excess of plant uptake, these minerals can accumulate in the soil or leach to nearby waterways [8]. In large enough concentrations, trace minerals, such as $\mathrm{Co}, \mathrm{Cu}, \mathrm{Mn}$, and $\mathrm{Zn}$, can be toxic to plants, microorganisms, and aquatic organisms [9-11].

Horses are often supplemented trace minerals in amounts that exceed their requirements, leading to increased fecal excretion [12]. In other species, many authors have investigated the mobility of trace minerals, particularly $\mathrm{Cu}$ and $\mathrm{Zn}$, from compost [13-15]. To the authors' knowledge, there have been no studies examining the mobility of trace minerals in equine-sourced compost. A better understanding of the mobility of trace minerals in equine compost is necessary for quantifying the environmental risks associated with storing and applying equine compost to land.

The effect of the horse's diet on compost quality and characteristics has received little attention. In general, there is a positive linear relationship between dietary mineral intake and fecal excretion [16]. Thus, the more mineral fed to a horse, the greater the concentration in the feces, and subsequently in the compost. In addition to the amount of mineral available for leaching, the form of the mineral in the compost dictates how readily available that mineral is for leaching, run-off, or plant uptake potential [13]. Horses are typically supplemented trace minerals in organic or inorganic form, which are believed to have different bioavailabilities to the horse [17]. However, it is unknown how these dietary mineral forms will behave in compost.

The objective of this study was to quantify mineral content and leaching potential of compost created from the feces of horses fed different amounts, and forms (organic and inorganic), of trace minerals. We hypothesized that feeding more trace minerals would increase compost mineral concentration and increase the amount of mineral that leached from the compost. Our second hypothesis was that the form of the added dietary trace minerals would impact the leaching potential of those minerals.

\section{Materials and Methods}

The animal portion of this experiment was approved by the Institutional Animal Care and Use Committee at the University of Kentucky.

Fecal material for composting was obtained from nine horses $(9.1 \pm 2.1 \mathrm{yr} ; 600.9 \pm 50.6 \mathrm{~kg}$ initial BW) fed three different treatment pellets, with varying sources and levels of trace minerals. The experiment was designed as a replicated $3 \times 3$ Latin square, with three treatments assigned to three blocks of three horses, each over three time periods. All horses received each of the three dietary treatments in a random order $(n=9$ per treatment). Dietary treatments were provided in a soybean-meal-based pellet with either no added trace minerals (CON), added inorganic trace minerals (ING), or added organic trace minerals (ORG). The ING and ORG treatments were formulated to contain the same amount of trace minerals, with the difference being source. The added trace minerals were cobalt $(\mathrm{Co})$, copper $(\mathrm{Cu})$, manganese $(\mathrm{Mn})$, and zinc $(\mathrm{Zn})$. The inorganic forms were provided as cobalt carbonate, copper sulfate, manganous oxide, and zinc oxide. The organic forms were provided as metal proteinates (BioPlex ${ }^{\circledR}$; Alltech, Nicholasville, KY, USA). The final feed analysis showed that ORG had lower levels of trace minerals compared with ING (Table 1), therefore horses fed ORG received $0.25 \%$ of body weight (BW) per day of the ORG pellet, while ING and CON received $0.2 \%$ of BW per day. Thus, the ING and ORG treatments received the same amount of minerals on a per $\mathrm{kg}$ BW basis.

Each treatment period consisted of a 5-days washout and a 16-days feeding period. Throughout the experiment, horses were kept in fields with ad libitum access to forage at all times. Horses also had unlimited access to water. During the washout, horses were only allowed to consume forage and the treatment pellet was withheld. During the feeding period, horses were fed their assigned treatment pellets in feed nosebags (Feedrite Feed Bag; Cashel Company, Granbery, TX, USA) once per day (08:00 h).

Fecal material was collected on day 16 of the feeding period. In the morning of day 16 , horses were brought into rubber-matted stalls without shavings, and all fecal material excreted from each horse 
over an 8-h period (08:00 to 16:00 h) was collected. Feces were collected from the floor immediately following defecation, and composited into bags that were kept closed to prevent moisture loss. At the end of the 8-h period composited feces from each horse were thoroughly mixed. Approximately $1.75 \mathrm{~kg}$ of wet feces was saved and stored at $-20^{\circ} \mathrm{C}$ for mineral analysis and leaching. Those data are reported in a companion paper [18]. The remaining fecal material for each horse was composted.

Table 1. Analyzed chemical composition (DM basis) of control, inorganic, and organic pellets.

\begin{tabular}{cccc}
\hline Item & CON & ING & ORG \\
\hline $\mathrm{DM}, \%$ & 90.4 & 90.7 & 90.9 \\
$\mathrm{CP}, \%$ & 33.1 & 32.4 & 37.5 \\
$\mathrm{NDF} \%$ & 13.8 & 13.1 & 13.3 \\
$\mathrm{ADF}, \%$ & 10.2 & 9.5 & 8.7 \\
$\mathrm{Ca}, \%$ & 3.97 & 3.78 & 3.89 \\
$\mathrm{P}, \%$ & 2.24 & 2.12 & 2.24 \\
$\mathrm{Mg} \%$ & 0.29 & 0.41 & 0.38 \\
$\mathrm{~K}, \%$ & 1.96 & 1.96 & 1.96 \\
$\mathrm{Na}, \%$ & 0.996 & 0.998 & 0.944 \\
$\mathrm{Fe}, \mathrm{mg} \mathrm{kg}^{-1}$ & 766 & 855 & 888 \\
$\mathrm{Zn}, \mathrm{mg} \mathrm{kg}^{-1}$ & 81 & 529 & 499 \\
$\mathrm{Cu}, \mathrm{mg} \mathrm{kg}^{-1}$ & 28 & 178 & 152 \\
$\mathrm{Mn}, \mathrm{mg} \mathrm{kg}^{-1}$ & 70 & 432 & 366 \\
$\mathrm{Co}, \mathrm{mg} \mathrm{kg}^{-1}$ & 0.93 & 1.88 & 2.00 \\
$\mathrm{Cr}, \mathrm{mg} \mathrm{kg}^{-1}$ & 13.2 & 10.4 & 13.4 \\
\hline
\end{tabular}

Pellets were custom formulated and produced by McCauley Bros., Versailles, KY. All minerals except Cr were analyzed by a commercial laboratory (Dairy One Forage Laboratory, Ithaca, NY, USA). Chromium was analyzed using inductively coupled plasma mass spectrometry (ICP-MS) owned by a laboratory in the College of Agriculture, Food, and the Environment at the University of Kentucky. Abbreviations: CON, control treatment; ING, inorganic treatment; ORG, organic treatment; $\mathrm{DM}$, dry matter; $\mathrm{CP}$, crude protein; NDF, neutral detergent fiber; $\mathrm{ADF}$, acid detergent fiber.

The composting process was conducted in an environmentally controlled room maintained at $24{ }^{\circ} \mathrm{C}$. Feces from each horse were placed in 5-gallon buckets ( $n=9$ per treatment). Long-stem wheat straw ( $\left.<0.005 \mathrm{mg} \mathrm{Co} \mathrm{kg}^{-1} \mathrm{DM} ; 0.9 \mathrm{mg} \mathrm{Cu} \mathrm{kg}^{-1} \mathrm{DM} ; 48 \mathrm{mg} \mathrm{Mn} \mathrm{kg}^{-1} \mathrm{DM} ; 6 \mathrm{Zn} \mathrm{kg}^{-1} \mathrm{DM}\right)$ was added to each bucket at a rate of $2.5 \%$ of fecal wet weight and thoroughly mixed in. Buckets were sealed with lids that had a rubber septum attached for gas sampling. After $14 \mathrm{~h}$, buckets were shaken by hand and a gas sample was pulled from each bucket using a gas-tight syringe. Gas samples were analyzed for carbon dioxide and methane using gas chromatography. Holes were then drilled into the 5-gallon buckets to provide aeration and the lids were left off the buckets. Temperature of the compost was monitored on a regular basis. Water was added as needed to keep compost moist and compost was aerated by manual turning as needed.

A subsample $(n=3)$ of compost was tested for $\mathrm{C}$ and $\mathrm{N}$ and it was determined that compost maturity was sufficient to stop the experiment by day 98 (C:N = 20:1). At this time, compost was weighed and dry matter (DM) was measured to determine DM disappearance (DMD). A sample was frozen for later analysis.

Compost samples were leached using an apparatus that simulates a rainfall event and allows for capture of the leachate. This method has been described elsewhere [18]. After leaching, the leached compost samples were dried at $55^{\circ} \mathrm{C}$ for $24 \mathrm{~h}$ and ground for analysis.

Pre-leached compost and leached compost samples were analyzed for minerals using inductively coupled plasma mass spectroscopy (ICP-MS) following acidic closed-vessel microwave digestion. An ICP-MS instrument (7500cx, Agilent Technologies, Santa Clara, CA, USA) was used to analyze for $\mathrm{Co}, \mathrm{Cu}, \mathrm{Mn}$, and $\mathrm{Zn}$. For the digestion, $0.25 \mathrm{~g}$ of dried and ground sample was weighed into Teflon digestion vessels. Ten milliliters of trace element grade nitric acid (VWR International LLC, Radnor, PA, USA) were added to each vessel for ICP-MS analysis. The following protocol was used to microwave 
digest the samples: ramp 20 to $25 \mathrm{~min}$, hold $15 \mathrm{~min}$ at $200{ }^{\circ} \mathrm{C}$, cool $15 \mathrm{~min}$ (MARS 6; CEM Corporation, Matthews, NC, USA). Following digestion, samples were diluted as needed for analysis. For quality control, digestion duplicates were included every 10 samples and a standard reference material (peach leaves; NIST, Gaithersburg, MD, USA) was included in the digestion and analysis procedure.

Concentrations of minerals in the pre-leached and leached compost samples were used to calculate the percent of minerals that leached. Mineral, DMD, and gas data were analyzed as a replicated $3 \times 3$ Latin square using an ANOVA (SAS Institute Inc., Cary, NC, USA). The model included dietary treatment, period, block, and horse within block. If significance was detected, means were separated using an LSD test. Differences among treatment means are indicated with the use of letters (' $a$ ', ' $b$ ', and ' $c$ ' for $p<0.05$ or ' $\alpha$ ' and ' $\beta$ ' for $0.05<p<0.10$ ); means followed by a similar letter do not differ from each other.

Simple correlations using Pearson's correlation coefficients were examined among the amounts of supplemented trace minerals $(\mathrm{Co}, \mathrm{Cu}, \mathrm{Mn}$, and $\mathrm{Zn})$ that leached from the compost. These correlations were made within treatments to examine if mineral form of the supplemented mineral affected the tendency to leach with other minerals. Only significant correlations with $\mathrm{r}>0.50$ were reported.

Significance was defined as $p<0.05$ and a trend as $0.05<p<0.10$.

\section{Results and Discussion}

\subsection{Gas Production and Dry Matter Disappearance}

Methane and carbon dioxide evolution was measured during the initial period of composting to assess microbial activity. No methane was detected and carbon dioxide production was not different among treatments in gas samples taken at $14 \mathrm{~h}(p>0.10$; Table 2$)$. The absence of methane in any of the samples indicates the lack of anaerobic fermentation processes occurring during the first $14 \mathrm{~h}$ of composting, which is desirable during composting. The rate of carbon dioxide production has been used as an indicator of aerobic microbial activity and respiration $[4,19]$. Since carbon dioxide production was similar among treatments, the rate of microbial activity during the first $14 \mathrm{~h}$ of composting is assumed to be similar among treatments as well.

During the composting process, microbial activity reduces the carbon and nitrogen content, resulting in a reduction in organic matter and production of carbon dioxide, ammonia, water, and organic acids [4]. Since there were no leaching losses or any way for the inorganic material to disappear from the composting system used here, the reduction in organic matter can be estimated by measuring DM disappearance. The DM disappearance averaged $50 \%$ across all treatments $(p>0.10$; Table 2). A comparable 50\% DM loss has also been reported in other studies composting equine manure and pelleted straw $[3,6]$.

Table 2. Compost dry matter disappearance after $98 \mathrm{~d}$, carbon dioxide, and methane production after $14 \mathrm{~h}$ from feces from horses fed the control, inorganic, and organic treatment pellets.

\begin{tabular}{cccccc}
\hline Item & CON & ING & ORG & SEM & $p$-Value \\
\hline $\mathrm{DMD}, \%$ & 50.8 & 50.2 & 49.5 & 1.4 & 0.812 \\
$\mathrm{CO}_{2}, \mathrm{mM} \mathrm{kg}^{-1} \mathrm{DM}$ & 19.7 & 18.8 & 17.4 & 0.82 & 0.148 \\
$\mathrm{CH}_{4}, \mathrm{mM} \mathrm{kg}^{-1} \mathrm{DM}$ & $\mathrm{ND}$ & $\mathrm{ND}$ & $\mathrm{ND}$ & - & - \\
\hline
\end{tabular}

Abbreviations: CON, control treatment; ING, inorganic treatment; ORG, organic treatment; SEM, standard error of the mean; $\mathrm{DMD}$, dry matter disappearance; $\mathrm{CO}_{2}$, carbon dioxide; $\mathrm{CH}_{4}$, methane. $\mathrm{ND}$, not detected.

\subsection{Mineral Content of Compost}

Compost from horses fed supplementary trace minerals (ING and ORG) had greater concentrations of the supplemented trace minerals ( $\mathrm{Co}, \mathrm{Cu}, \mathrm{Mn}$, and $\mathrm{Zn})$, which was expected $(p<0.05$; Table 3$)$. The only trace mineral that differed between the supplemented groups was $\mathrm{Zn} ; \mathrm{Zn}$ concentration was greater in the ING compost compared to the ORG compost $(p<0.05$; Table 3$)$. The reason why Zn 
concentration was greater in ING compost is unknown. The concentration of $\mathrm{Zn}$ was similar in the feces used to generate the ING and ORG composts [18]. Leaching losses were not possible in our compost system, so there would be no route for $\mathrm{Zn}$ to leach from any of the composts. Additionally, DM disappearance was not different among treatments, so Zn should be equally concentrated in the compost treatments due to similar DM losses.

Table 3. Mineral concentration of compost (DM basis), amount and percent of mineral that leached for $\mathrm{Co}, \mathrm{Cu}, \mathrm{Mn}$, and $\mathrm{Zn}$ for horses fed control, inorganic, and organic dietary treatments $(n=9$ per treatment).

\begin{tabular}{|c|c|c|c|c|c|}
\hline Item & $\mathrm{CON}$ & ING & ORG & SEM & $p$-Value \\
\hline \multicolumn{6}{|l|}{ Cobalt } \\
\hline Compost, $\mathrm{mg} \mathrm{kg}^{-1}$ & $1.15^{\mathrm{b}}$ & $1.55^{\mathrm{a}}$ & $1.62^{\mathrm{a}}$ & 0.09 & 0.007 \\
\hline Leached, $\mathrm{mg} 10 \mathrm{~g}^{-1} \mathrm{DM}$ & $0.0032^{\beta}$ & $0.0036^{\alpha, \beta}$ & $0.0040^{\alpha}$ & 0.0003 & 0.085 \\
\hline Leached, \% & 25.25 & 23.63 & 22.52 & 1.62 & 0.496 \\
\hline \multicolumn{6}{|l|}{ Copper } \\
\hline Compost, $\mathrm{mg} \mathrm{kg}^{-1}$ & $20.73^{b}$ & $56.95^{a}$ & $56.92^{\mathrm{a}}$ & 3.45 & $<0.0001$ \\
\hline Leached, $\mathrm{mg} 10 \mathrm{~g}^{-1} \mathrm{DM}$ & $0.027^{\mathrm{b}}$ & $0.076^{\mathrm{a}}$ & $0.097^{\mathrm{a}}$ & 0.0094 & $<0.0001$ \\
\hline Leached, $\%$ & 11.66 & 13.84 & 15.41 & 1.57 & 0.249 \\
\hline \multicolumn{6}{|l|}{ Manganese } \\
\hline Compost, $\mathrm{mg} \mathrm{kg}^{-1}$ & $481.23^{b}$ & $603.56^{\mathrm{a}}$ & $613.50^{\mathrm{a}}$ & 27.17 & 0.007 \\
\hline Leached, $\mathrm{mg} 10 \mathrm{~g}^{-1} \mathrm{DM}$ & 0.99 & 0.82 & 1.03 & 0.11 & 0.379 \\
\hline Leached, $\%$ & 18.58 & 14.63 & 15.87 & 1.62 & 0.221 \\
\hline \multicolumn{6}{|l|}{ Zinc } \\
\hline Compost, $\mathrm{mg} \mathrm{kg}^{-1}$ & $93.10^{c}$ & $255.93^{a}$ & $224.16^{b}$ & 10.45 & $<0.0001$ \\
\hline Leached, $\mathrm{mg} 10 \mathrm{~g}^{-1} \mathrm{DM}$ & $0.18^{c}$ & $0.62^{\mathrm{a}}$ & $0.42^{b}$ & 0.055 & $<0.0001$ \\
\hline Leached, $\%$ & $16.68^{b}$ & $24.17^{\mathrm{a}}$ & $16.67^{b}$ & 2.04 & 0.016 \\
\hline
\end{tabular}

Within a row, treatment means followed by a similar letter $\left({ }^{\mathrm{a}-\mathrm{c}}\right)$ do not statistically differ $(p<0.05)$. Within a row, treatment means followed by a similar Greek letter $(\alpha, \beta)$ do not tend to statistically differ $(0.05<p<0.10)$. Abbreviations: CON, control treatment; ING, inorganic treatment; ORG, organic treatment; SEM, standard error of the mean.

Due to the decrease in organic matter content, concentrations of all minerals were greater in the compost compared to the pre-composted feces, which were reported in another study [18]. Briefly, feces from horses supplemented with trace minerals (ING and ORG) had significantly greater concentrations of $\mathrm{Cu}$ and $\mathrm{Zn}$, and tended to have greater concentrations of Co compared to CON [18]. Other studies have also reported an increase in mineral concentration after composting [6]. Despite greater concentrations of minerals in compost, these minerals have been shown to be more stable and less water soluble [6]. The form of the mineral changes throughout the composting process and can thus affect the solubility of that mineral [13].

\subsection{Mineral Leaching from Compost}

The $\mathrm{pH}$ of the leachate collected in the middle or at the end of the simulated rainfall was unaffected by treatment ( $p>0.10$; Table A1, Appendix A). Values for $\mathrm{pH}$ ranged from 7.01 to 7.11. However, $\mathrm{pH}$ did increase from the middle to the end of the rainfall event for all treatments $(p<0.05)$.

The amount and percentage of mineral that leached was calculated and is shown in Table 3. Additionally, correlations were examined between the amount of trace minerals that leached from the compost across treatments (Table 4) and within treatments (Tables 5-7). 
Table 4. Pearson correlations $(r)$ between amount $(\mathrm{mg})$ of minerals that leached from compost samples across all treatments ( $n=54$; all horses across all treatments in duplicate).

\begin{tabular}{cccc}
\hline & $\mathbf{C u}$ & $\mathbf{M n}$ & $\mathbf{Z n}$ \\
\hline $\mathrm{Co}$ & $0.483^{*}$ & $0.610^{*}$ & 0.189 \\
$\mathrm{Cu}$ & - & $0.532 *$ & $0.629^{*}$ \\
$\mathrm{Mn}$ & & - & $0.319^{*}$ \\
$\mathrm{Zn}$ & & & - \\
\hline
\end{tabular}

* Indicates that correlation is significant $(p<0.05)$.

Table 5. Pearson correlations $(r)$ between amount $(\mathrm{mg})$ of minerals that leached from compost samples for the control (CON) treatment $(n=18$; all horses in $\mathrm{CON}$ in duplicate).

\begin{tabular}{cccc}
\hline & $\mathbf{C u}$ & $\mathbf{M n}$ & $\mathbf{Z n}$ \\
\hline $\mathrm{Co}$ & 0.020 & 0.416 & -0.055 \\
$\mathrm{Cu}$ & - & $0.572^{*}$ & $0.843^{*}$ \\
$\mathrm{Mn}$ & & - & $0.734^{*}$ \\
$\mathrm{Zn}$ & & & - \\
\hline * Indicates that correlation is significant $(p<0.05)$
\end{tabular}

Table 6. Pearson correlations $(r)$ between amount $(\mathrm{mg})$ of minerals that leached from compost samples for the inorganic (ING) treatment ( $n=18$; all horses in ING in duplicate).

\begin{tabular}{cccc}
\hline & $\mathbf{C u}$ & $\mathbf{M n}$ & $\mathbf{Z n}$ \\
\hline $\mathrm{Co}$ & 0.284 & 0.391 & -0.408 \\
$\mathrm{Cu}$ & - & $0.789{ }^{*}$ & 0.335 \\
$\mathrm{Mn}$ & & - & 0.204 \\
$\mathrm{Zn}$ & & & - \\
\hline * Indicates that correlation is significant $(p<0.05)$.
\end{tabular}

Table 7. Pearson correlations $(r)$ between amount $(\mathrm{mg})$ of minerals that leached from compost samples for the organic (ORG) treatment $(n=18$; all horses in ORG in duplicate).

\begin{tabular}{cccc}
\hline & $\mathbf{C u}$ & $\mathbf{M n}$ & $\mathbf{Z n}$ \\
\hline $\mathrm{Co}$ & $0.645^{*}$ & $0.920 *$ & $0.745^{*}$ \\
$\mathrm{Cu}$ & - & $0.752 *$ & $0.878^{*}$ \\
$\mathrm{Mn}$ & & - & $0.865 *$ \\
$\mathrm{Zn}$ & & & - \\
\hline * Indicates that correlation is significant $(p<0.05)$.
\end{tabular}

A greater amount of $\mathrm{Cu}$ leached from ING and ORG composts compared to CON compost $(p<0.05$; Table 3) and a greater amount of Co tended to leach more from ING and ORG compared to CON $(p<0.10 ;$ Table 3). However, when expressed as a percentage of initial concentrations, the differences among treatments disappeared ( $p>0.10$; Table 3$)$, indicating that the amount of $\mathrm{Co}$ and $\mathrm{Cu}$ that leached from compost was mostly related to the initial concentration. Asada et al. [20] demonstrated an increase in soil Zn mobility as soil Zn concentration increased with compost application. Others have suggested that the total concentration of mineral in the compost is unrelated to the leaching potential and the form of the mineral is more important in determining solubility [13]. Perhaps in the current study, the forms of $\mathrm{Co}$ and $\mathrm{Cu}$ were more similar among composts due to similar compost management and so leaching potential was more dependent on the amount available to leach. Thus, just examining the concentration of $\mathrm{Co}$ and $\mathrm{Cu}$ in compost may be sufficient to predict the amount that will leach.

There were no differences in Mn leaching among treatments, despite having differences in compost Mn concentration among treatments. Interestingly, the strongest leaching correlations across treatments 
all involved $\mathrm{Mn}$, with the only other strong correlations being the $\mathrm{Cu} / \mathrm{Zn}$ correlations for $\mathrm{CON}$ and ORG. In the ORG compost, Mn was correlated with Co and $\mathrm{Zn}(p<0.05)$, which were correlations lacking for ING.

In the CON compost, there was a strong correlation between $\mathrm{Mn}$ and $\mathrm{Zn}(r=0.734)$. It may be possible that as $\mathrm{Zn}$ leached from the CON compost, $\mathrm{Mn}$ was leached as well, causing a greater percent of $\mathrm{Mn}$ to leach than expected based on initial compost $\mathrm{Mn}$ concentration. The $\mathrm{Cu} / \mathrm{Zn}$ correlations were also quite strong in the CON and ORG compost $(r>0.80)$, so $\mathrm{Cu}$ may have been associating with $\mathrm{Zn}$ as it leached as well. This $\mathrm{Cu} / \mathrm{Zn}$ association may explain why $\mathrm{Mn}$ was associated with $\mathrm{Cu}$ leaching in the ING compost.

The pattern for $\mathrm{Zn}$ leaching was slightly different. The lowest amount of $\mathrm{Zn}$ that leached was in CON, but there was also a significant difference between ING and ORG, with the ING compost leaching the greatest amount of $\mathrm{Zn}(p<0.05$; Table 3). The ING compost also had the greatest amount of $\mathrm{Zn}$, so a greater amount of $\mathrm{Zn}$ leaching from ING compost was expected. When expressed as a percent of initial $\mathrm{Zn}$ concentration, ING compost leached the greatest percent of $\mathrm{Zn}$, with CON and ORG similar to each other ( $p<0.05$; Table 3$)$. Thus, leaching from ING did not appear to depend solely on initial $\mathrm{Zn}$ concentrations and may depend on other factors, such as mineral form. A study using swine manure reported that $\mathrm{Zn}$ in compost is primarily bound to inorganics instead of organic material [13]. This suggests that $\mathrm{Zn}$ is only weakly bound to organic ligands when compared to the inorganic forms and is more soluble in water during the leaching process. Thus, both the amount of $\mathrm{Zn}$ and, perhaps more importantly, the form of $\mathrm{Zn}$ should be considered when formulating diets for horses in order to reduce the potential for $\mathrm{Zn}$ leaching from equine waste.

Across all treatments, the leaching patterns of most of the supplemented minerals are correlated with each other, with the exception of Co and Zn (Table 4). However, when broken out by treatment, the influence that the mineral source had on the overall correlations becomes apparent. The ORG compost had the strongest correlations for all minerals (Table 7), while the ING compost only had one significant correlation, between $\mathrm{Mn}$ and $\mathrm{Cu}$ (Table 6). The CON compost was in between, with the only significant correlations for $\mathrm{Cu} / \mathrm{Mn}, \mathrm{Cu} / \mathrm{Zn}$, and $\mathrm{Mn} / \mathrm{Zn}$ (Table 5). The quantity and strength of the correlations in the ORG compost was surprising, as the trace minerals in the diet of the ORG group were chelated (proteinates) and were not expected to interact or associate with other compounds [21]. However, because the trace minerals in the ORG group were all similar in form and relatively inert, perhaps they were all affected similarly in the compost and all leached in similar amounts, thus appearing to be correlated with each other. In the ING compost, the minerals were not chelated and may have been free to form associations with other compounds-likely negatively charged compounds as all the supplemented minerals have positive charges in ionic form-and thus did not appear to be correlated with each other during leaching. Minerals in the CON compost were all endogenous to the feed ingredients and thus were likely mostly in the organic form [22]. The CON compost also had less trace mineral available to leach and interact; so both form and amount may explain why CON correlations were intermediate to ING and ORG compost.

Feces collected from this study was also leached and results were published in a companion paper [18]. The pattern in leaching among treatments was similar in feces and compost. For example, the ING treatments leached the greatest amount of $\mathrm{Zn}$ and the CON treatments leached the least amount of $\mathrm{Zn}$ for both feces and compost [18]. However, compared to feces, minerals in compost were less mobile, as evidenced by a lower percentage of leached mineral.

Reduced mineral mobility after composting has been demonstrated in compost generated from manure from other species as well. In swine manure, bioavailability of $\mathrm{Cu}, \mathrm{Zn}$, and $\mathrm{Pb}$ decreased during composting [14]. Composting also decreased leaching potential of $\mathrm{Cu}$ in chicken manure [15]. The reduced mobility of minerals in the compost is likely due to mineral form. The water-soluble fraction of minerals is considered to be the most biologically active, as this fraction is most available for plant uptake [23]. However exchangeable ( $\mathrm{KNO}_{3}$-extractable) and complexed (DPTA-extractable) minerals are also considered to be relatively bioavailable for plant uptake [24], and thus may be more 
susceptible to leaching. One study using swine compost demonstrated that $\mathrm{Cu}$ was primarily bound to organic matter, so leachability of $\mathrm{Cu}$ was highly related to dissolved organic $\mathrm{C}$ [13]. Dissolved organic $\mathrm{C}$ generally decreases with increasing compost maturity, so more immature compost has more dissolved organic $\mathrm{C}$, and thus, a greater potential for $\mathrm{Cu}$ leaching [13]. In contrast, $\mathrm{Zn}$ and $\mathrm{Mn}$ were primarily bound in inorganic forms (i.e., carbonates and oxides) instead of being captured by organic matter. As a result, their leachability was not as readily influenced by dissolved organic $C$ content [13].

\section{Conclusions}

The addition of trace minerals to the diet of horses increased the concentration and the leaching potential of those minerals in compost generated from manure. Additionally, the source of dietary trace minerals (organic or inorganic) affected the leaching potential for $\mathrm{Zn}$ in equine compost, with inorganic $\mathrm{Zn}$ resulting in more $\mathrm{Zn}$ leaching than organic $\mathrm{Zn}$. Diet, including mineral concentration and mineral source, affects the composition and environmental impact of compost, so care should be taken when formulating diets for horses. More research is required to assess effects of other dietary changes on compost quality and environmental risk.

Author Contributions: Conceptualization, M.B.-H. and K.A.D.; methodology, M.B.-H.; formal analysis, A.L.F.; investigation, A.L.F. and M.B.-H.; resources, M.B.-H. and A.L.F.; data curation, A.L.F. and M.B.-H.; visualization, A.L.F.; writing-original draft preparation, A.L.F.; writing-review and editing, A.L.F., M.B.-H., and K.A.D.; supervision, M.B.-H.; project administration, M.B.-H. and A.L.F.; funding acquisition, M.B.-H. All authors have read and agreed to the published version of the manuscript.

Funding: This study was supported by the Kentucky Agriculture Experiment Station. Funding for the research was provided by Alltech, Inc., Nicholasville, KY, USA.

Acknowledgments: The authors would like to acknowledge the Maine Chance farm staff, Susan Hayes, and Andrea Crum for their assistance in managing horses and collecting samples for this study. Kristen Krebs is acknowledged for her help in the laboratory.

Conflicts of Interest: This research was supported by Alltech Inc., who also provided the product for the study.

\section{Appendix A}

Table A1. $\mathrm{pH}$ of leachate collected in the middle or at the end of the simulated rainfall event.

\begin{tabular}{cccccc}
\hline Time Collected & Control & Inorganic & Organic & SEM & $p$-Value \\
\hline Middle $\mathrm{pH}$ & 7.05 & 7.02 & 7.01 & 0.03 & 0.6313 \\
End $\mathrm{pH}$ & 7.11 & 7.06 & 7.06 & 0.03 & 0.3693 \\
\hline
\end{tabular}

\section{References}

1. USDA-NRCS. Agricultural Waste Field Handbook; USDA: Washington, DC, USA, 2000.

2. Komar, S.; Miskewitz, R.; Obropta, C.; Bamka, W.; Mickel, R. Evaluation of nutrient runoff from three equine stall waste storage systems. Appl. Eng. Agric. 2010, 265, 827-832. [CrossRef]

3. Komar, S.; Miskewitz, R.; Westendorf, M.; Williams, C. Effects of bedding type on compost quality of equine stall waste: Implications for small horse farms. J. Anim. Sci. 2012, 903, 1069-1075. [CrossRef] [PubMed]

4. Bernal, M.P.; Alburquerque, J.; Moral, R. Composting of animal manures and chemical criteria for compost maturity assessment. A review. Bioresour. Technol. 2009, 10022, 5444-5453. [CrossRef] [PubMed]

5. Westendorf, M.; Joshua, T.; Komar, S.; Williams, C.; Govindasamy, R. Case study: Manure management practices on New Jersey equine farms. Prof. Anim. Sci. 2010, 261, 123-129. [CrossRef]

6. Keskinen, R.; Saastamoinen, M.; Nikama, J.; Särkijärvi, S.; Myllymäki, M.; Salo, T.; Uusi-Kämppä, J. Recycling nutrients from horse manure: Effects of bedding type and its compostability. Agric. Food Sci. 2017, 262, 68-79. [CrossRef]

7. Larney, F.J.; Hao, X. A review of composting as a management alternative for beef cattle feedlot manure in southern Alberta, Canada. Bioresour. Technol. 2007, 9817, 3221-3227. [CrossRef] [PubMed] 
8. Lin, L.; Liao, X.-D.; Luo, X.-G. Nutritional strategies for reducing nitrogen, phosphorus and trace mineral excretions of livestock and poultry. J. Integr. Agric. 2017, 1612, 2815-2833.

9. Nagpal, N. Water Quality Guidelines for Cobalt: Water Protection Section, Water, Air and Climate Change Branch; Technical Report; Ministry of Water, Land, and Air Protection: Victoria, BC, Canada, 2004.

10. Coppenet, M.; Golven, J.; Simon, J.; Le Corre, L.; Le Roy, M. Chemical evolution of soils in intensive animal-rearing farms: The example of Finistere. Agronomie 1993, 132, 77-83. [CrossRef]

11. Harford, A.J.; Mooney, T.J.; Trenfield, M.A.; van Dam, R.A. Manganese toxicity to tropical freshwater species in low hardness water. Environ. Toxicol. Chem. 2015, 3412, 2856-2863. [CrossRef] [PubMed]

12. Harper, M.; Swinker, A.; Staniar, W.; Welker, A. Ration evaluation of Chesapeake Bay watershed horse farms from a nutrient management perspective. J. Equine. Vet. Sci. 2009, 529, 401-402. [CrossRef]

13. Hsu, J.-H.; Lo, S.-L. Characterization and extractability of copper, manganese, and zinc in swine manure composts. J. Environ. Qual. 2000, 292, 447-453. [CrossRef]

14. Miaomiao, H.; Wenhong, L.; Xinqiang, L.; Donglei, W.; Guangming, T. Effect of composting process on phytotoxicity and speciation of copper, zinc and lead in sewage sludge and swine manure. Waste Manag. 2009, 292, 590-597. [CrossRef] [PubMed]

15. Xu-Dong, W.; Xian-Ni, C.; Ali, A.; Shuai, L.; Li-Lan, L. Dynamics of humic substance-complexed copper and copper leaching during composting of chicken manure. Pedosphere 2010, 202, 245-251. [CrossRef]

16. Coenen, M. Macro and trace elements in equine nutrition. In Equine Applied and Clinical Nutrition.; Goer, R.J., Harris, P.A., Coenen, M., Eds.; W.B. Saunders: Philadelphia, PA, USA, 2013; pp. 190-228.

17. NRC. Nutrient Requirements of Horses; National Academies Press: Washington, DC, USA, 2007.

18. Fowler, A.; Brummer-Holder, M.; Dawson, K. Dietary trace mineral level and source affect fecal bacterial mineral incorporation and mineral leaching potential of equine feces. Sustainability 2019, 11, 7107. [CrossRef]

19. Hue, N.; Liu, J. Predicting compost stability. Compost. Sci. Util. 1995, 32, 8-15. [CrossRef]

20. Asada, K.; Toyota, K.; Nishimura, T.; Ikeda, J.-I.; Hori, K. Accumulation and mobility of zinc in soil amended with different levels of pig-manure compost. J. Environ. Sci. Health Part B 2010, 454, 285-292. [CrossRef] [PubMed]

21. Spears, J.W. Organic trace minerals in ruminant nutrition. Anim. Feed Sci. Technol. 1996, 581-582, $151-163$. [CrossRef]

22. Spears, J.W. Minerals in forages. In Forage Quality, Evaluation, and Utilization; Fahey, G., Ed.; ASA, CSSA, SSSA: Madison, WI, USA, 1994; pp. 281-317.

23. Leita, L.; De Nobili, M. Water-soluble fractions of heavy metals during composting of municipal solid waste. J. Environ. Qual. 1991, 201, 73-78. [CrossRef]

24. Petruzzelli, G.; Lubrano, L. Evaluation of Heavy Metals Bioavailability in Compost Treated Soils; De Bertoldi, M., Ed.; Elsevier Applied Science Publ: London, UK, 1987. 